\title{
Minimal Plant Responsiveness to Summer Water Pulses: Ecophysiological Constraints of Three Species of Semiarid Patagonia
}

\author{
Rodolfo A. Golluscio, Valeria Sigal Escalada, and Juliana Pérez \\ Authors are Instituto de Investigaciones Fisiológicas y Ecológicas vinculadas a la Agricultura (University of Buenos Aires/Consejo Nacional de \\ Investigaciones Científicas y Tecnicas [UBA/CONICET]), Cátedra de Forrajicultura, Facultad de Agronomía, Universidad de Buenos Aires, \\ Av San Martín 4453, Buenos Aires, Argentina.
}

\begin{abstract}
In arid ecosystems, a few large summer rains frequently differentiate wet years from dry ones. However, use of this additional water by plants has limited experimental evidence. We applied a $16-\mathrm{mm}$ summer water pulse ( $12 \%$ of mean annual precipitation) to two plant communities of the Patagonian steppe, and compared responses of three dominant species, which can be ordered by decreasing xerophytism and increasing rooting depth and summer activity: 1) colapiche, evergreen dwarf shrub (Nassanvia glomerulosa [Lag.] Don); 2) coirón amargo, evergreen grass (Stipa speciosa Trin. et Rupr.); and 3) neneo, drought deciduous shrub (Mulinum spinosum [Cav.] Pers.). Shallow-rooted species (S. speciosa and N. glomerulosa), which use water from dry soil layers, showed a greater leaf water potential response to watering than deep-rooted species (M. spinosum). Leaf water potential response was greater and quicker in xerophytic species than in mesophytic ones (N. glomerulosa $>S$. speciosa $>$ M. spinosum). However, this response only translated into leaf conductance and transpiration responses for coirón amargo, probably because the species with winter phenological cycle (N. glomerulosa) is less able to utilize summer water inputs than species with a summer phenological cycle (S. speciosa). The lack of response of deep-rooted M. spinosum in leaf conductance, transpiration, and photosynthesis may have been due to the high leaf water potential of control plants. Instead, in S. speciosa and N. glomerulosa net photosynthesis decreased below zero following watering, suggesting the start of growth pulses. The complex chain of plant processes triggered by rainfall, and the constraints imposed to different species by rooting depth, phenology, and xerophytism, could explain the frequent low response to both large rainfall events and above-average rainfall years in this arid community. Our results suggest that, paradoxically, water may be suboptimally used at local scales in arid rangeland ecosystems.
\end{abstract}

\section{Resumen}

En los ecosistemas áridos, unas pocas lluvias grandes de verano frecuentemente diferencian los años húmedos de los años secos. Sin embargo, hay limitadas pruebas experimentales del uso de esta agua adicional por las plantas. Nosotros aplicamos un pulso de $16 \mathrm{~mm}$ de agua durante el verano ( $12 \%$ del promedio anual de precipitación) en dos comunidades de plantas de la estepa patagónica, y comparamos las respuestas de las tres especies dominantes, que pueden ser ordenadas por la disminución en el xerofitismo y el aumento en la profundidad de enraizamiento y la actividad estival: 1) colapiche, arbusto siempreverde enano (Nassauvia glomerulosa [Lag.] Don); 2) coirón amargo, pasto perenne (Stipa speciosa Trin. et Rupr.); y 3) neneo, arbusto cuyas hojas se secan en la época de sequía (Mulinum spinosum [Cav.] Pers.). Las especies de raíces más superficiales (S. speciosa y N. glomerulosa), que utilizan el agua de las capas de suelo seco, mostraron una mayor respuesta al riego en el potencial agua de la hoja que la especie de raíces profundas (M. spinosum). La respuesta del potencial agua de la hoja fue mayor y más rápida en las especies xerofíticas que en las especies mesofíticas (N. glomerulos $>$ S. speciosa $>$ M. spinosum). Sin embargo, esta respuesta sólo se tradujo en respuestas en la conductancia de la hoja y la transpiración en el coirón amargo, probablemente porque la especie con ciclo fenológico invernal (N. glomerulosa) es menos capaz de utilizar los aportes estivales de agua que las especies con ciclo fenológico estival (S. speciosa). La falta de respuesta de la especie de raíces profundas M. spinosum en la conductancia de la hoja, la transpiración y la fotosíntesis puede haberse debido al alto potencial hídrico de la hoja de las plantas control. En cambio, la fotosíntesis neta en S. speciosa y N. glomerulosa disminuyó por debajo de cero tras el riego, lo que sugiere el inicio de pulsos de crecimiento. La compleja cadena de procesos de las plantas desencadenados por las lluvias, y las limitaciones impuestas a diferentes especies por la profundidad radical, la fenología y el xerofitismo, podrían explicar la baja frecuencia de respuesta tanto a los eventos grandes de precipitación como a los años de precipitaciones por encima del promedio en esta comunidad árida. Nuestros resultados sugieren que, paradójicamente, el agua puede ser utilizada subóptimamente a escalas locales en los ecosistemas de pastizales áridos.

Key Words: altered precipitation, hierarchy of plant responses, life forms, plant strategies, plant water relations

Research was done in the Experimental Field of Río Mayo (Instituto Nacional de Tecnología Agropecuaria, Argentina), and funded by Fundación Bunge y Born (PICT 15124; PICT 00463/07), UBA (G044, G062), and CONICET (PIP 5963). UBA supported a fellowship for V.S.E.

Correspondence: Rodolfo A. Golluscio, IFEVA (UBA/CONICET), Cátedra de Forrajicultura, Facultad de Agronomía, Universidad de Buenos Aires, Av San Martín 4453, Buenos Aires, Argentina. Email: gollusci@ifeva.edu.ar

Manuscript received 30 September 2008; manuscript accepted 30 November 2008.

\section{INTRODUCTION}

Forage availability is closely linked to water availability in arid rangeland ecosystems. Mean aboveground net primary production (ANPP), the main food source for range-fed animals, was linearly correlated with mean annual precipitation (MAP) for several North American rangelands (Sala et al. 1988). However, interannual analysis of the ANPP vs. annual 
precipitation relationship shows that, within some specific sites with MAP $\leq 400 \mathrm{~mm}$, actual ANPP also increases with actual annual precipitation but it does not attain the mean ANPP of sites historically subjected to that actual precipitation (Lauenroth and Sala 1992; Paruelo et al. 1999). The Patagonian steppe, which has a very low MAP $(150 \mathrm{~mm})$, exhibits low responsivity of additional increases in ANPP with high actual precipitation (Golluscio and Oesterheld 2007).

Existence of vegetational and/or biogeochemical constraints has been proposed to explain the low responsivity of arid ecosystems to above-average annual precipitations (Paruelo et al. 1999). If biogeochemical causes were the main constraint to responses of arid ecosystems to above-average precipitation, it would be removed by strategic fertilization. However, ecosystems with less than $300 \mathrm{~mm}$ of MAP rarely show significant responses to nitrogen or phosphorus fertilization (Guevara et al. 2000). Our general hypothesis is that structural constraints may play an important role in explaining the low responsivity of arid ecosystems to above-average precipitations. These structural constraints include low cover $(50 \%)$, low rate of increase in response to above-average precipitation, and also a set of ecophysiological adaptations allowing plants to cope with drought, but unavoidably impeding them to profit from pulsed water inputs.

The first point of our conceptual model is that in arid zones wet years often differ from dry years only in the occurrence of some few large summer water pulses (Golluscio et al. 1998). However, several field experiments did not find plant responses to large rainfall events (Fernández 2007). For example, North American desert shrubs tend to show positive short-term responses to large summer rainfall in terms of leaf water potential, but not in terms of growth (Snyder et al. 2004). The causes of this lack of growth response remain unclear; deep roots, phenological constraints, or nutrient colimitation have been proposed (Snyder et al. 2004). Paradoxically, if plants in some arid ecosystems were actually unable to use large summer water pulses, these water-limited ecosystems would be highly inefficient in the use of water when it is abundant. The elucidation of this issue is vital to understanding water cycles, and to predicting forage availability, in arid ecosystems.

The second point of our conceptual model is that plant response to large summer rainfall depends on the same three attributes characterizing the strategies of drought resistance: 1 ) spatial evasion (rooting depth), 2) temporal evasion (phenology), and 3) tolerance (xerophytism; Golluscio et al. 2005). The first requisite to detecting plant responses to watering is that it must cause an increase in soil water potential in layers where plant roots are concentrated. However, the ability of different species to profit from rare water pulses depends not only on the density of the active roots in wetted soil layers, but also on the cost-benefit relationship between production of new roots and/ or photosynthetic enzymes and additional carbon gain (Schwinning et al. 2003). This cost-benefit relationship depends on the phenological stage of each species (Mordacq et al. 1986): the higher the dependence of a plant species on winter rainfall, the higher the cost of using summer rainfall, and, consequently, the lower the ability to use it (Schwinning et al. 2003). Xerophytic plants, in turn, may show higher photosynthetic rates at low soil water potential and quicker responses to watering than mesophytic plants (Orians and Solbrig 1977; Westoby 1980).

In this article, we applied a large summer water pulse $(12 \%$ of MAP) and compared short-term (10-d) responses of three central-west Patagonian species that dominate two different plant communities. These communities coexist under the same arid and winter-concentrated precipitation regime but on different soils. One of these communities is the shrub-grass steppe dominated by coirón amargo (Stipa speciosa Trin. et Rupr.; grass with roots concentrated in the upper $30 \mathrm{~cm}$ of soil) and neneo (Mulinum spinosum [Cav.] Pers.; drought deciduous shrub with roots concentrated at a 45-60-cm depth; Golluscio et al. 2005). The other community is the semidesert dominated by the dwarf shrub colapiche (Nassauvia glomerulosa [Lag.] Don) with roots concentrated in the first $15 \mathrm{~cm}$ of soil (Schulze et al. 1996). The shrub-grass steppe and the semidesert grow on sandy and clayed patches of a soil mosaic, respectively (Golluscio et al. 1982). The clayed soils were formed before the uplift of the Andes, when Patagonia was covered by exuberant forests, and are somewhere buried below a more modern sandy soil covered by shrub-grass steppes (Paruelo et al. 2007). Because of its higher soil depth and its coarser texture (causing less evaporative losses and lower water content at conventional wilting point of $-1.5 \mathrm{MPa}$ ), the former has a water balance more favorable for plant growth than the latter (Noy Meir 1973). In addition, as revealed by remotely sensed data, the shrub-grass steppe has more summer phenological and physiological activity than the semidesert (Paruelo et al. 2004). As a consequence, the three species can be ordered by decreasing xerophytism and increasing rooting depth and summer activity: colapiche, coirón amargo, and neneo.

Our objective was to test the following hypotheses: 1) the deepest-rooted species (neneo) would have less significant short-term responses to the summer water pulse than the shallow-rooted ones, 2) leaf water potential responses of shallow-rooted species would translate in more significant photosynthetic responses in species with more summer phenological activity (coirón amargo) than in the species with less summer activity (colapiche), and 3) among the shallowrooted species, the more xerophytic species (colapiche) would show more rapid and significant leaf water potential responses to watering than the less xerophytic species (coirón amargo).

\section{METHODS}

\section{Site Description}

The experiment was performed on two neighboring stands of the shrub-grass steppe and the semidesert plant communities, located in the Experimental Farm of the Instituto Nacional de Tecnología Agropecuaria, Río Mayo, Center West Patagonia, Argentina (lat $45^{\circ} 41^{\prime} \mathrm{S}$, long $70^{\circ} 16^{\prime} \mathrm{W}$ ). Mean annual rainfall is $136 \mathrm{~mm}, 70 \%$ of which falls during the cold season from May to September (Fernández et al. 1991). Monthly mean temperature ranges between $2{ }^{\circ} \mathrm{C}$ in July and $14^{\circ} \mathrm{C}$ in January (Sala et al. 1989). The shrub-grass steppe stand corresponds to the community of Stipa speciosa Trin. et Rupr., Stipa humilis Cav., Adesmia volkmanni Philippi, Berberis heterophylla Juss., and Poa lanuginosa Poir. (Golluscio et al. 1982). The soils there (Petrocalcic Calciorthids, Golluscio et al. 1982) have a sandy 
layer up to $40 \mathrm{~cm}$ deep, below which lies a sandy-clay layer with high gravel and calcium carbonate content (Paruelo et al. 1988). The semidesert stand corresponds to the community of Nassanvia glomerulosa (Lag.) Don, Chuquiraga aurea Skottsb., and Chuquiraga kingii Ball (Golluscio et al. 1982). The soils (Paleoargids; Golluscio et al. 1982) here have a thin, shallow sandy layer (frequently less than $5-10 \mathrm{~cm}$ ), followed by a heavily clayed layer with less gravel content than the shrubgrass steppe soil layers. Measurements done previously in sites neighboring the studied communities show that the semidesert has about one-third of the overall biomass ( 0.47 vs. $1.48 \mathrm{~kg}$ dry matter $\left.\cdot \mathrm{m}^{-2}\right)$, twice the below- to aboveground biomass ratio (2.2 vs. 1.1), and one-fourth of the leaf area index (0.10 vs. 0.40) of shrub-grass steppe (Schulze et al. 1996).

\section{Experimental Layout}

We compared watered vs. control plants of coirón amargo, colapiche, and neneo in January, a time when the soil is drying (Sala et al. 1989), but both communities are still phenologically active (Paruelo et al. 2004). The water pulse was supplied on 20 January 1996. The amount of precipitation during the previous year was slightly above normal $(174 \mathrm{~mm})$, but only $91 \mathrm{~mm}$ occurred from autumn to spring, and then the 1995-1996 growing season can be considered normal. We randomly selected 32 adult plants of each species, and randomly assigned the two treatments (watering vs. control) among them. The maximum distance between measured plants was $50 \mathrm{~m}$. As only one stand was studied for each plant community, we cannot rigorously extrapolate our results to the entire communities compared. We performed destructive (leaf water potential and soil water content and temperature at different depths) and nondestructive (stomatal conductance, net photosynthesis, and transpiration) measurements on Days 1, 2, 6, and 10 post water pulse. We divided each of the 16 watered and 16 control plants of each species into four groups of four plants each. We used three of the groups to make destructive measurements on Days 1,2, and 6, and the fourth group to make nondestructive measurements every day, and also destructive measurements at the end of Day 10.

We watered to the depth where most roots ( $>80 \%$ biomass) are concentrated in each community: $30 \mathrm{~cm}$ in semidesert and $75 \mathrm{~cm}$ in shrub-grass steppe (Schulze et al. 1996). We used the soil water retention curves for the shrub-grass steppe (Paruelo et al. 1988) and the semidesert (R. A. Golluscio, unpublished data, 1987) to calculate the amount of water to be added. Assuming the soil was at wilting point until the desired depth, and that field capacity is between 0.01 and $0.03 \mathrm{MPa}$ (mean $0.02 \mathrm{MPa}$ ), the water added was equivalent to a rainfall of $16 \mathrm{~mm}$ in both communities and represented $12 \%$ of MAP. We watered with a sprinkling pot within a circular area where most of the roots of each individual plant were concentrated. The diameters of these circular areas were $50 \mathrm{~cm}$ for coirón amargo (Soriano et al. 1987), $100 \mathrm{~cm}$ for neneo (Fernández and Paruelo 1988 ), and $50 \mathrm{~cm}$ for colapiche (ad hoc visual inspection).

\section{Soil Water Content and Temperature}

We measured the $0-10-\mathrm{cm}$ and $10-20-\mathrm{cm}$ soil depth gravimetric water content $(\%)$ at the end of the canopy projection of each species each measuring day. The intense daily measure- ment protocol made it difficult to obtain soil samples from depths below $20 \mathrm{~cm}$. Soils have high stone and gravel content, and the extraction of an individual sample from $60 \mathrm{~cm}$ requires a hole $80 \mathrm{~cm}$ in diameter and takes $1.5-3 \mathrm{~h}$ of labor. We sequentially obtained soil samples from both soil depths with the use of an iron cylindrical core with an inner diameter of $5.5 \mathrm{~cm}$. Samples were stored in hermetic plastic bags, and were weighed in a laboratory. The weights were recorded when the samples were fresh, and then again after the samples were dried for $72 \mathrm{~h}$ in an oven at $105^{\circ} \mathrm{C}$. Soil temperature was recorded at midday on Days 1, 3, 6, and 10 with two thermistors NTH2974A (GM Electronics, Buenos Aires, Argentina), buried at depths of $5 \mathrm{~cm}$ and $15 \mathrm{~cm}$ in the canopy projection end of each plant of colapiche and neneo reserved to be harvested on Day 10. The thermistors were previously calibrated in growth chambers measuring their electric resistance under known temperature conditions (five different temperatures between $15^{\circ} \mathrm{C}$ and $35^{\circ} \mathrm{C}$ for each thermistor, $r^{2}>0.95$ in all cases).

\section{Leaf Water Potential}

Midday (1300-1500 hours) leaf water potential was measured with a pressure chamber (Scholander et al. 1965) especially designed for arid zones, which is able to record pressures of up to $10 \mathrm{MPa}$ (Biocontrol Instruments, Buenos Aires, Argentina). We used expanding leaves of coirón amargo and small green branches (10-15-cm length) of neneo and colapiche. We followed the recommendations of Turner (1988) to measure leaf water potential rigorously. In order to make all the measurements essentially at the same time, we reduced to three the number of replications for each day and treatment, by randomly discarding one of the original four replications. We discarded the measurement of predawn leaf water potential; because of the lack of light it takes even more time than midday measurement, leading to an unacceptably low number of replications.

\section{Conductance and Gas Exchange}

We measured instantaneous leaf-mass-based daily transpiration $\left(E\right.$, in $\left.\mu \mathrm{mol} \cdot \mathrm{g}^{-1} \cdot \mathrm{s}^{-1}\right)$ and photosynthesis $(A$, in $\mu \mathrm{mol} \cdot \mathrm{kg}^{-1} \cdot \mathrm{s}^{-1}$ ) rates (Wright et al. 2004). The complex morphology of the branches of colapiche, with minuscule leaves arranged by groups of 5-10 within spheric structures $0.5 \mathrm{~cm}$ in diameter (glomerules; Cabrera 1971), prevented us from measuring leaf area and calculating leaf-area-based leaf conductance, net photosynthesis, or transpiration. We used a portable infrared gas analyzer system (Li-6200; Li-Cor Inc., Lincoln, NE) with a $40 \times 20 \times 20 \mathrm{~cm}$ hermetic chamber with a 3 -mm-thick plastic polycarbonate covered in Teflon (Lexan) specially constructed for this experiment (as in Parkinson and Day 1990). Soil-plant gas exchange was prevented with the use of a plastic cover. $E$ and $A$ were measured on entire plants of colapiche and coirón amargo, but only on branches of neneo (an approximately hemispherical canopy of 1-m diameter). Instantaneous measurements were made at 700, 1100, 1500, and 2000 hours from Day 1 to Day 10, on the same plants of the three species, but on a different branch of neneo each day. We harvested the sampled tillers or branches, and determined the dry weight of green leaves oven dried $72 \mathrm{~h}$ at $80^{\circ} \mathrm{C}$. To obtain a mean daily $E$ or $A$, we averaged instantaneous data, 


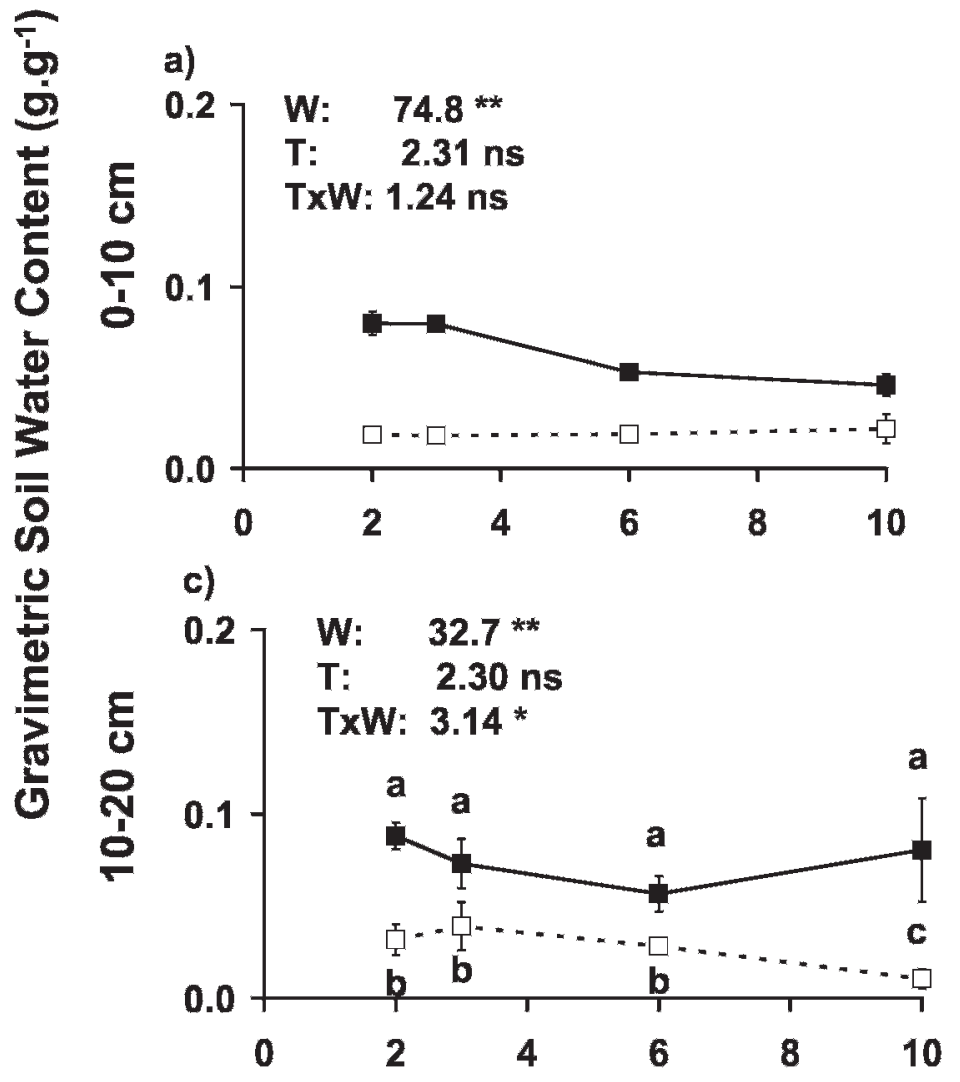

b)

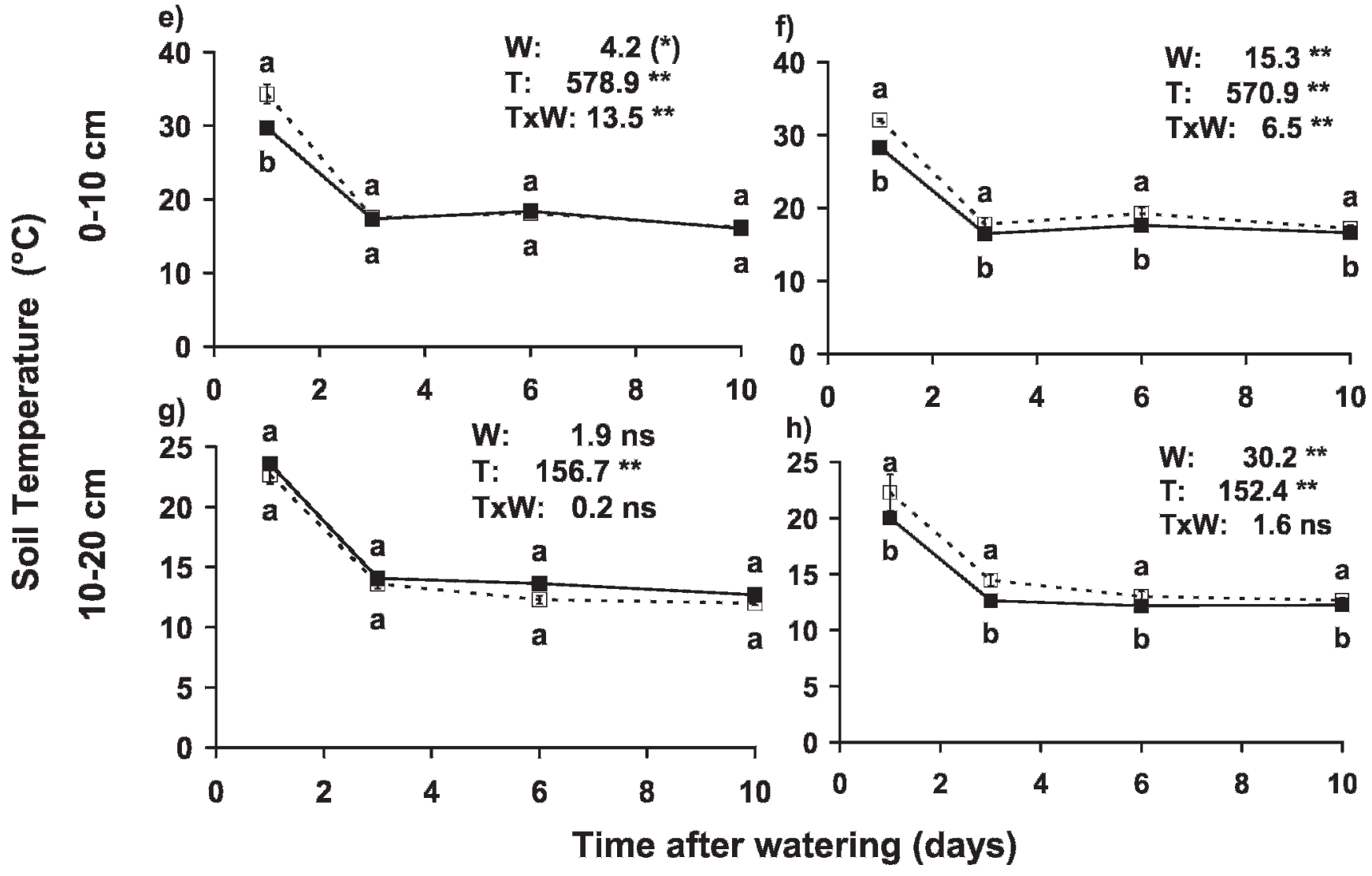

Figure 1. Dynamics of soil water content in the shrub-grass steppe (a, c) and semidesert communities (b, d) at two soil depths: 0-10 cm (a, b) and 10-20 cm (c, d). Dynamics of soil temperature in the shrub-grass steppe $(\mathbf{e}, \mathbf{g})$ and semidesert communities (f, h) at two soil depths: 0-10 cm $(\mathbf{e}, \mathbf{f})$ and $10-20 \mathrm{~cm}(\mathbf{g}, \mathbf{h})$. Dotted lines plus empty symbols indicate control plants; full lines and full symbols, watered plants. In all panels we show 
weighting them by the proportion of the illuminated period of the day represented by each one, under the assumption of stomatal closure in the absence of light (Lambers et al. 1998). We calculated mean daily leaf-mass-based leaf conductance ( $g_{\text {mass }}$, in $\mathrm{mmol} \cdot \mathrm{g}^{-1} \cdot \mathrm{s}^{-1}$ ) as the ratio between mean daily transpiration rate and the mean daily leaf to air vapor pressure deficit.

We calculated the leaf to air vapor pressure deficit (LAVPD; $\mathrm{kPa})$ as the difference between the vapor pressure between leaf $\left(e_{\text {leaf }}\right)$ and air within chamber $\left(e_{\text {air }}\right)$. We assumed that 1$)$ the air within the leaf is water saturated, and then $e_{\text {leaf }}=e$ of saturation at the leaf temperature $\left(e_{\text {sat }}\right)$, and 2$)$ leaf temperature is equal to air temperature. To test this second assumption, we measured the leaf temperature with specially designed clamping tools, because the standard thermocouple provided with the LiCor 6200 was not adapted to the leaf morphology of the three species. Within each clamping tool $(40 \times 8 \times 8 \mathrm{~mm})$ we put a $1 \times 2 \mathrm{~mm}$ thermistor NTH2074A (GM Electronics). We then made simultaneous measurements of leaf and air temperature on three plants of each species at 1300, 1700, and 1900 hours on the day previous to beginning the experiment, and compared them by means of linear regression. Leaf temperature was closely correlated to air temperature (air temperature $=-1.3+1.06 \times$ leaf temperature), with $y$-intercept not differing from 0 , slope not differing from 1 , and the three species being explained by the same model $\left(r^{2}=0.94, n=27, P<0.0001\right)$.

\section{Statistical Analyses}

For each species, we used a one-way analysis of variance (ANOVA; control vs. watered), with a level of significance of $\alpha=0.05$. For those variables sampled on different individuals on each measuring date, we included time as a second factor with four levels. For the variables sampled on the same plant throughout the experiment, we included time as a split plot factor within the two main treatments (ANOVA test with repeated measurements).

\section{RESULTS}

\section{Soil Responses to Watering}

Watering increased soil water content up to $20 \mathrm{~cm}$ in both communities (Figs. 1a-1d). In addition, it caused some soil cooling. In the semidesert, the water pulse caused a reduction of the soil temperature from Day 1 to Day 10 at both the $0-10-\mathrm{cm}$ and $10-20-\mathrm{cm}$ soil depths (Figs. 1e-1h). In the shrub-grass steppe this cooling effect of watering was only evident on Day 1 and in the upper soil layer. In both communities the soil was warmer in the upper than in the lower layer.

\section{Plant Responses to Watering}

According to the soil water response pattern, leaf water potential of the three species increased after watering, more significantly for colapiche than for neneo and coirón amargo (Figs. 2a-2c). However, the ranking of significance in the responses of the leaf conductance was the opposite: coirón amargo showed a highly significant increase, whereas neneo did not show any response, and colapiche showed a significant decrease (Figs. 2d-2f). The species with the lowest initial leaf water potential also showed the highest leaf water potential response. Stomatal conductance and leaf water potential of control water-stressed plants (estimators of drought) were lower in colapiche than in coirón amargo and neneo. The difference in leaf water potential between watered and control plants on the second day after watering, indicative of time response (Sala and Lauenroth 1982), was more significant for colapiche than for coirón amargo and neneo.

The response of transpiration to the water pulse was consistent with the response observed in leaf conductance, because neneo did not show any response (Fig. 3a), coirón amargo showed a highly significant increase in response to watering (Fig. 3b), and colapiche had a significant decrease (Fig. 3c). The response pattern of net photosynthesis to the water pulse was similar to that of transpiration, except that coirón amargo showed a marked decrease in net photosynthesis (Figs. 3d-3f). The decrease in net photosynthesis of coirón amargo was only evident until the sixth day (Fig. 3e), and was higher, attaining values well below zero, than the decrease in colapiche, which rarely attained values below zero. The net photosynthesis level of control water-stressed plants was close to zero in all three species. Mean daily water use efficiency was low $\left(-2 \mathrm{mmol} \mathrm{CO}_{2} \cdot \mathrm{mol}\right.$ water ${ }^{-1}$ to $3 \mathrm{mmol} \mathrm{CO}_{2} \cdot \mathrm{mol}$ water ${ }^{-1}$ ), and showed essentially the same patterns described for net photosynthesis: it was higher for neneo than for coirón amargo and colapiche, and did not change with watering in neneo but decreased with watering in the other two species (data not shown).

The decrease in plant transpiration in response to watering observed in colapiche was not only associated with the decrease in stomatal conductance, but also with a fall in LAVPD $\left(\mathrm{LAVPD}=e_{\text {leaf }}-e_{\text {air }}\right)$ in response to watering, which was also observed in coirón amargo but not in neneo (Table 1). In the case of colapiche, this LAVPD decrease was associated with two responses to watering: the increase in $e_{\text {air }}(P=0.09$; Table 1), and the slightly significant decrease in leaf temperature $(P=0.12$; Table 1$)$, which produced a decrease in $e_{\text {leaf }}$. The evaporative demand showed marked differences among days and explained some covariation of plant responses between watered and control plants, evident for example at Day 6 in Figures 2 and 3 (data not shown).

\section{DISCUSSION}

Short-term (Days 1-10) responses of the three species to a large summer water pulse partially supported our expectation that

the $F$ values obtained from the time $(\mathrm{T}) \times$ watering $(\mathrm{W})$ analysis of variance tests. Symbols indicate the statistical significance of each effect: ns indicates $\left.P>0.10 ;{ }^{*}\right), 0.10>P>0.05 ;{ }^{*}, 0.05>P>0.01 ;{ }^{*}, P<0.01$. Different letters indicate significant differences $(P<0.05$ or $0.10>P>0.05$, when between brackets) between watered and control plants each day (only when $T \times W$ interactions were statistically significant). Vertical bars indicate standard errors. 

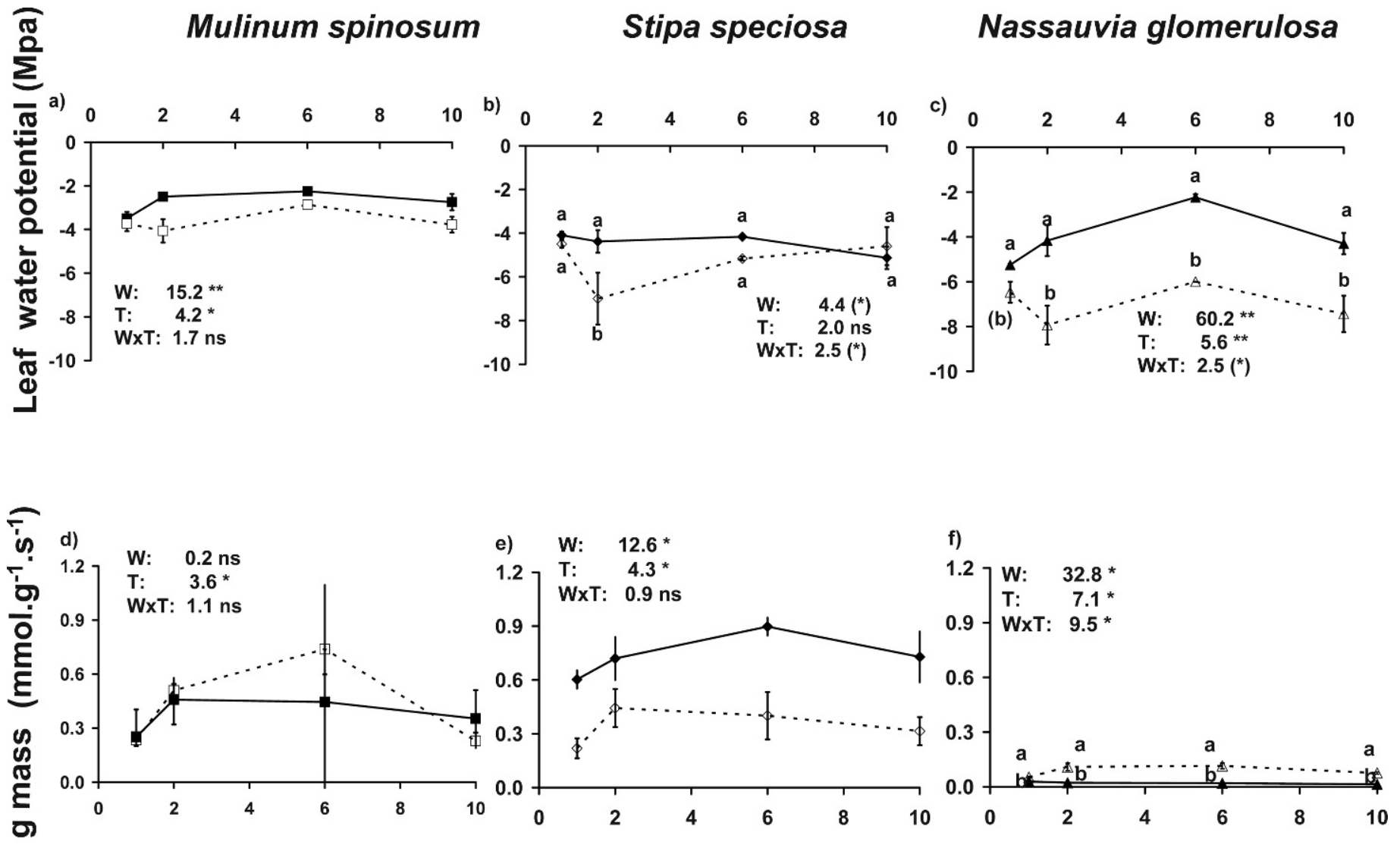

\section{Time after watering (days)}

Figure 2. Dynamics of leaf water potential (a-c) and stomatal conductance (d-f) for neneo (Mulinum spinosum; a, d), coirón amargo (Stipa speciosa; b, e), and colapiche (Nassauvia glomerulosa; c, f). Dotted lines plus empty symbol indicate control plants; full lines and full symbols, watered plants. In all panels we show the $F$ values obtained from the time $(T) \times$ watering $(\mathrm{W})$ analysis of variance tests. Symbols indicate the statistical significance of each effect: ns indicates $P>0.10 ;\left({ }^{*}\right), 0.10>P>0.05 ;{ }^{*}, 0.05>P>0.01 ;{ }^{* *}, P<0.01$. Different letters indicate significant differences $(P<0.05$ or $0.10>P>0.05$, when between brackets) between watered and control plants each day (only when $\mathrm{T} \times \mathrm{W}$ interactions were statistically significant). Vertical bars indicate standard errors.

deep-rooted species (neneo) would be unable to use this water pulse (Hypothesis 1). Although watering caused an increase in leaf water potential in all three species, this response did not cause an increase in leaf conductance of neneo. Both annual herbs and drought deciduous shrubs usually show a relatively wide range of water potential where leaf conductance is near the maximum value, and an abrupt decrease in the conductance when the water potential is below the lowest limit of this leaf water potential range (Schwinning and Ehleringer 2001). Because there was no change in leaf conductance in response to watering, there was also no change in leaf-level net photosynthesis of neneo. Instead, as expected, both shallow-rooted species showed significant photosynthetic responses to watering, which consisted of a below-zero decrease of net photosynthesis. In addition, such response of the shallow-rooted species was more significant for coirón amargo than for colapiche, the most winter-rainfalldependent species (Hypothesis 2).

Species compared here partially supported the models proposed by Orians and Solbrig (1977) and Westoby (1980). Leaf water potential and conductance, but not net photosynthesis, of control plants were ordered according to our initial xerophytism ranking of species, based on morphological traits and soil texture: colapiche (shallow-rooted, clayed soils) $<$ coirón amargo (shallow-rooted, sandy soils) $<$ neneo (deeprooted, sandy soils). The velocity of the leaf water potential response to watering mirrored the order of xerophytism: colapiche $>$ coirón amargo $>$ neneo (Hypothesis 3 ).

The ranking of leaf water potential increase before watering was not mirrored by the responses in leaf conductance and transpiration, for which the highest values were observed in $S$. speciosa rather than in colapiche. The high increase in leaf conductance and transpiration rate of $S$. speciosa may have been due to the opportunistic behavior of grasses, which have young leaves and the capability to produce new leaves under favorable conditions (Golluscio et al. 2005). Young leaves have higher leaf conductance than older ones, and also a higher ability to increase it in response to an improvement in plant water status (Lambers et al. 1998). The decrease in leaf conductance of colapiche in response to watering could have been associated with the decrease in air and soil temperature induced by watering. Such cooling effect of watering could have caused a decrease in root water absorption, and then in leaf conductance, of watered colapiche plants (Lambers et al. 1998). 

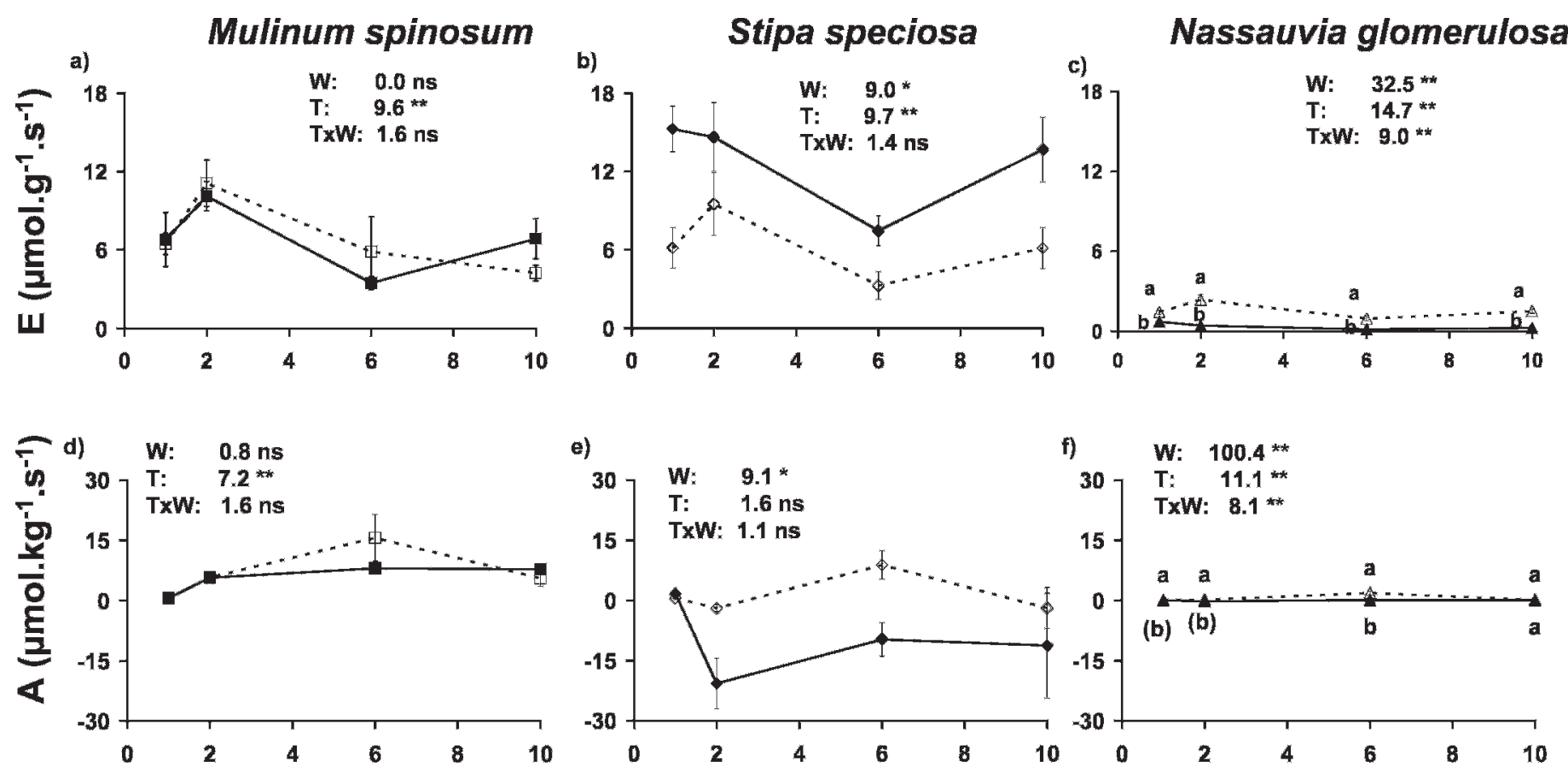

\section{Tìme after watering (days)}

Figure 3. Dynamics of transpiration $(E ; \mathbf{a}-\mathbf{c})$, and net photosynthesis $(A ; \mathbf{d}-\mathbf{f})$ for neneo (Mulinum spinosum; a, d), coirón amargo (Stipa speciosa; b, e), and colapiche (Nassauvia glomerulosa; c, f) along the $10 \mathrm{~d}$ after watering. Dotted lines plus empty symbols indicate control plants; full lines and full symbols, watered plants. In all panels we show the $F$ values obtained from the time $(T) \times$ watering $(W)$ analysis of variance tests. Symbols indicate the statistical significance of each effect: ns indicates $P>0.10 ;\left({ }^{*}\right), 0.10>P>0.05 ;{ }^{*}, 0.05>P>0.01 ;{ }^{\star *}, P<0.01$. Different letters indicate significant differences $(P<0.05$ or $0.10>P>0.05$, when between brackets) between watered and control plants each day (only when $\mathrm{T} \times \mathrm{W}$ interactions were statistically significant). Vertical bars indicate standard errors.

Our results agree with the model proposing the existence of a hierarchy of response variables involving increasing plant energy expenditure (Schwinning et al. 2003; Schwinning and Sala 2004). At one end of the hierarchy, the increase of leaf water potential has the lowest carbon and energy cost, whereas, at the opposite end, leaf and root production have the highest carbon and energy costs. We found that 1) leaf water responses to watering coincided with the increase in water availability in the soil layers where each species has roots, 2) species that showed leaf water potential responses could not show any response in another hierarchically subordinated kind of responses (e.g., $\Psi$ vs. $g_{\text {mass }}$ of neneo), 3) plants without responses in stomatal conductance did not show responses in net photosynthesis (neneo), and 4) photosynthetic responses of plants to the large summer water pulse were inversely related to their dependence on winter rainfall (the decrease in net photosynthesis was higher in coirón amargo than in colapiche).

\section{IMPLICATIONS}

The complex chain of passive and active plant processes and the constraints imposed by rooting depth, phenology, and xerophytism strongly condition the responses of the entire plant community to a large summer water pulse. Large rainfall events often differentiate wet from dry years; as such our results may contribute to explain the relatively low response to both large rainfall events (Bates et al. 2006; Fernández 2007) and wet

Table 1. Leaf to air vapor pressure deficit (LAVPD; $\mathrm{kPa})$, air temperature $\left(T_{\text {air }} ;{ }^{\circ} \mathrm{C}\right)$, and air vapor pressure $\left(e_{\text {air }}\right.$; hPa) obtained for the three plant species in watered and control treatments (mean values of four sampling dates). ${ }^{1}$

\begin{tabular}{|c|c|c|c|c|}
\hline & Watering treatment & LAVPD (kPa) & $T_{\text {air }}\left({ }^{\circ} \mathrm{C}\right)$ & $e_{\text {air }}(\mathrm{hPa})$ \\
\hline \multirow[t]{2}{*}{ Neneo (Mulinum spinosum [Cav.] Pers.) } & Watered & $1.94 \mathrm{~ns}$ & $19.9 \mathrm{~ns}$ & $5.1 \mathrm{~ns}$ \\
\hline & Control & $1.93 \mathrm{~ns}$ & $19.8 \mathrm{~ns}$ & $5.0 \mathrm{~ns}$ \\
\hline \multirow[t]{2}{*}{ Coirón amargo (Stipa speciosa Trin. et Rupr.) } & Watered & $1.84\left(^{*}\right)$ & $19.9 \mathrm{~ns}$ & $6.0 \mathrm{~ns}$ \\
\hline & Control & $1.95\left(^{*}\right)$ & $20.1 \mathrm{~ns}$ & $5.2 \mathrm{~ns}$ \\
\hline \multirow[t]{2}{*}{ Colapiche (Nassauvia glomerulosa [Lag.] Don) } & Watered & 1.82 * & $19.7 \mathrm{~ns}, \dagger$ & $5.8\left(^{\star}\right)$ \\
\hline & Control & 1.97 * & $20.1 \mathrm{~ns}, \dagger$ & $4.9\left(^{*}\right)$ \\
\hline
\end{tabular}

${ }^{1}$ Symbols indicate significant differences between watering treatments within each species: ns indicates $P>0.10 ;\left({ }^{*}\right), 0.10>P>0.05 ;{ }^{*}, P<0.05 ; \uparrow$, difference significant at $P=0.12$. 
years (Lauenroth and Sala 1992; Paruelo et al. 1999) frequently found in arid communities. Plant communities rich in shallowrooted summer-active species may profit more from intense summer rainfall than those rich in winter-active or deep-rooted species. The chance of recording plant responses must be greater for the plant processes with the lowest energy expenditure (e.g., increase in leaf water potential) than for those requiring higher energy expenditures (e.g., net photosynthesis). Our results support the paradox that water may be locally suboptimally used in arid rangeland ecosystems, which are extremely water limited. Additionally, in Patagonian shrub-grass steppes growing on shallow sandy soils, erosive processes triggered by overgrazing would uncover buried clay soils formed in past geological ages and induce the replacement of original vegetation by less productive, more xerophytic plant communities. As a consequence, rangeland management must be extremely careful in such sites.

\section{ACKNOWLEDGMENTS}

We acknowledge Alberto Soriano's initial stimulus, the suggestions made by J. M. Paruelo, A. Grimoldi, R. Fernández, E. Ploschuk, P. Insausti, and S. Perelman, and field and lab assistance from P. Roset, M. Nogués Loza, J. Mercau, P. Gundel, and J. C. Villardi.

\section{LITERATURE CITED}

Bates, J., T. Svejcar, R. Miller, and R. Angell. 2006. The effects of precipitation timing on sagebrush steppe vegetation. Journal of Arid Environments 64:670-697.

Cabrera, A. L. 1971. Compositae. In: M. Correa [ed.]. Flora Patagónica. Volume 8(7). Buenos Aires, Argentina: Colección Científica, INTA. 432 p.

Fernández, R. J. 2007. On the frequent lack of response of plants to rainfall events in arid areas. Journal of Arid Environments 68:688-691.

Fernández, R. J., and J. M. Paruelo. 1988. Root systems of two Patagonian shrubs: a quantitative description using a geometrical method. Journal of Range Management 41:220-223.

Fernández, R. J., O. E. Sala, and R. A. Golluscio. 1991. Woody and herbaceous aboveground production of a Patagonian steppe. Journal of Range Management 44:434-437.

Golluscio, R. A., R. J. C. León, and S. B. Perelman. 1982. Caracterización fitosociológica de la estepa del Oeste de Chubut: su relación con el gradiente ambiental. Boletín de la Sociedad Argentina de Botánica 21:299-324.

Golluscio, R. A., and M. Oesterheld. 2007. Water use efficiency of 25 co-existing Patagonian species growing under different soil water availability. Oecologia 154:207-217.

Golluscio, R. A., M. Oesterheld, and M. R. Aguiar. 2005. Phenology of twenty-five Patagonian species related to their life form. Ecography 28:273-282.

Golluscio, R. A., O. E. Sala, and W. K. Lauenroth. 1998. Differential use of large summer rainfall events by shrubs and grasses: a manipulative experiment in the Patagonian steppe. Oecologia 115:17-25.

Guevara, J. C., C. R. Stasi, and H. N. Le Houérou. 2000. N and P fertilization on rangeland production in Midwest Argentina. Journal of Range Management 53:410-414.

Lambers, H., F. S. Chapin, and T. L. Pons. 1998. Plant physiological ecology. New York, NY, USA: Springer. $540 \mathrm{p}$.

Lauenroth, W. K., and O. E. Sala. 1992. Long-term forage production of North American shortgrass steppe. Ecological Applications 2:397-403.
Mordacq, L., M. Mousseau, and E. Deleens. 1986. A ${ }^{13} \mathrm{C}$ method of estimation of carbon allocation to roots in a young chestnut coppice. Plant, Cell and Environment 9:735-740.

Noy Meır, I. 1973. Desert ecosystems: environment and producers. Annual Review of Ecology and Systematics 4:25-51.

Orians, G. H., AND O. T. Solbrig. 1977. A cost-income model of leaves and roots with special reference to arid and semiarid areas. American Naturalist 111:677-690.

Parkinson, K. J., And W. Day. 1990. Design and testing of leaves cuvettes for use in measuring photosynthesis and transpiration. In: I. Hashimoto, P. J. Kramer, H. Nonami, and B. R. Strain [EDS.]. Measurement techniques in plant science. San Diego, CA, USA: Academic Press. p. 207-228.

Paruelo, J. M., M. R. Aguiar, and R. A. Golluscio. 1988. Soil water availability in the Patagonian arid steppe: gravel content effect. Arid Soil Research and Rehabilitation 2:67-74.

Paruelo, J. M., R. A. Golluscio, J. P. Guerschman, A. Cesa, V. V. Jouve, and M. F. Garbulsky. 2004. Regional scale relationships between structure and functioning. The case of the Patagonian steppes. Global Ecology and Biogeography 13:385-395.

Paruelo, J. M., E. G. Jobbágy, M. Oesterheld, R. A. Golluscio, and M. R. Aguiar. 2007. The grasslands and steppes of Patagonia and the Rio de la Plata plains. In: T. Veblen [ED.]. The physical geography of South America. New York, NY, USA: Oxford University Press. p. 232-248.

Paruelo, J. M., W. K. Lauenroth, I. Burke, and 0. E. Sala. 1999. Grassland precipitation-use efficiency varies across a resource gradient. Ecosystems 2:64-68.

Sala, O. E., R. A. Golluscio, W. K. Lauenroth, and A. Soriano. 1989. Resource partitioning between shrubs and grasses in the Patagonian steppe. Oecologia $81: 501-505$

Sala, O. E., and W. K. LauenRoth. 1982. Small rainfall events: an ecological role in semiarid regions. Oecologia 53:301-304.

Sala, 0. E., W. S. Parton, L. A. Joyce, and W. K. Lauenroth. 1988. Primary production of the central grassland region of the United States. Ecology 69:40-45.

Scholander, P. R., H. T. Hammel, E. O. Bradstreet, and E. A. Hemmingsten. 1965. Sap pressure in vascular plants. Science 148:339-346.

Schulze, E. D., H. A. Mooney, O. E. Sala, E. G. Jobbágy, N. Buchmann, G. Bauer, J. Canadell, R. B. Jackson, J. Loreti, M. Oesterheld, and J. R. Ehleringer. 1996. Rooting depth, water availability, and vegetation cover along an aridity gradient in Patagonia. Oecologia 108:503-511.

Schwinning, S., and J. R. Ehleringer. 2001. Water use trade-offs and optimal adaptations to pulse-driven arid ecosystems. Journal of Ecology 89:464-480.

SchWInNING, S., AND O. E. SALA. 2004. Hierarchy of responses to resource pulses in arid and semi-arid ecosystems. Oecologia 141:211-220.

Schwinning, S., B. Starr, and J. R. Ehleringer. 2003. Dominant cold desert plants do not partition warm season precipitation by event size. Oecologia 136:252-260.

Snyder, K. A., L. A. Donovan, J. J. James, R. L. Tiller, and J. H. Richards. 2004. Extensive summer water pulses do not necessarily lead to canopy growth of Great Basin and northern Mojave Desert shrubs. Oecologia 141:325-334.

Soriano, A., R. A. Golluscio, and E. H. Satorre. 1987. Spatial heterogeneity of the root systems of grasses in the Patagonian arid steppe. Bulletin of the Torrey Botanical Club 114:103-108.

TURNER, N. C. 1988. Measurement of plant water status by the pressure chamber technique. Irrigation Science 9:289-308.

WESTOBY, M. 1980. Elements of a theory of vegetation dynamics in arid rangelands. Israel Journal of Botany 28:169-194.

Wright, I. J., P. B. Reich, M. Westoby, D. Ackerly, Z. Baruch, F. Bongers, J. CavenderBares, T. Chapin, J. Cornelissen, M. Diemer, J. Flexas, E. Garnier, P. Groom, J. Gulias, K. Hikosaka, B. Lamont, T. Lee, W. Lee, C. Lusk, J. Midgley, M. Navas, Ü. Ninemets, J. Oleksyn, N. Osada, H. Poorter, P. Poot, L. Prior, V. Pyankov, C. Roumet, S. Thomas, M. Tuoelker, E. Veneklaas, and R. Villar. 2004. The worldwide leaf economics spectrum. Nature 428:821-827. 